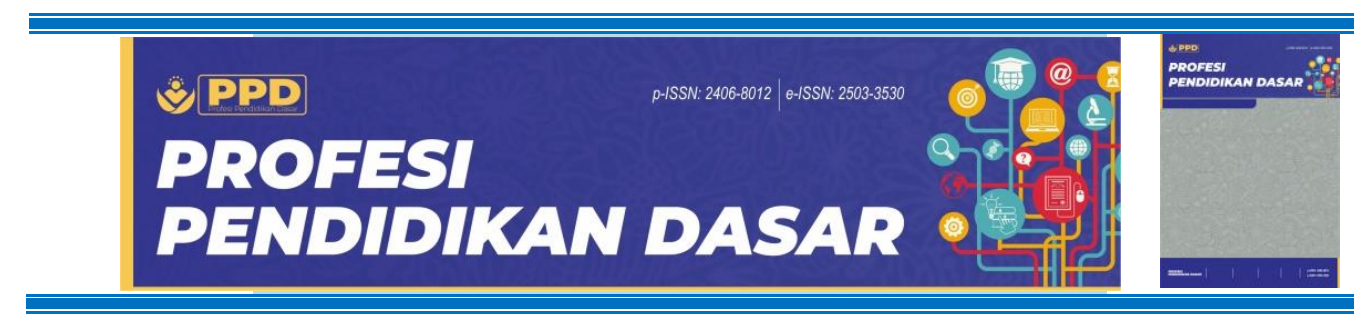

\title{
Analyzing The Use of The Year Four, Theme Three Student Book of the 2013 Curriculum to Build Environmental Awareness
}

\author{
Mentari Deka Handayani ${ }^{1 *}$, Laili Etika Rahmawati ${ }^{2}$, Yeny Prastiwi ${ }^{3}$, Eko Supriyanto ${ }^{4}$, \\ Choiriyah Widyasari ${ }^{5}$ \\ 1,2,3,4,5 Universitas Muhammadiyah Surakarta, Surakarta, Indonesia \\ *Email: q200180009@student.ums.ac.id
}

\begin{tabular}{|c|c|}
\hline \multicolumn{2}{|c|}{$\begin{array}{l}\text { Submitted: 2020-07-21 } \\
\text { Accepted: 2021-03-08 } \\
\text { Published: 2021-07-21 }\end{array}$} \\
\hline Keywords: & Abstract \\
\hline $\begin{array}{l}\text { environmental } \\
\text { awareness; } \\
\text { student books; } \\
2013 \text { curriculum }\end{array}$ & $\begin{array}{l}\text { The } 2013 \text { Curriculum emphasizes the cultivation of individual values. There are } \\
18 \text { values to be instilled, one of which is caring for the environment. These values } \\
\text { are taught through daily teaching and learning activities. Environmental } \\
\text { awareness is discussed in the year four student book under theme three. This } \\
\text { research is designed as a descriptive-qualitative study facilitating document } \\
\text { study. Data collection was done using the data analysis technique, content } \\
\text { analysis. The validity of the data was tested using semantic validity and stability } \\
\text { reliability. Results showed that the value of environmental awareness was } \\
\text { present in theme three of the year four student book and can be divided into } \\
\text { three indicators. These indicators include caring for plants, caring for animals } \\
\text { as well as caring for other human beings. In conclusion, theme three of the year } \\
\text { four student book is regarded as appropriate teaching material. }\end{array}$ \\
\hline
\end{tabular}

\section{INTRODUCTION}

\section{Background}

The 21st century is known as the disruption era or the millennial generation. Most daily activities have now shifted from face-to-face to virtual. The development of information and communication technology has grown at a speedy rate. This has also affected the constant development of gadgets. The millennial generation facilitates these gadgets daily, either for school, work, or even to communicate with their family or friends. The use of these gadgets has led to the reduction of live social interactions. Children have been found to experience difficulty adapting to their environment after actively using their devices (Rahmalah et al., 2019). This negatively impacts their environmental awareness. Some examples include the lack of social etiquette of greeting people around their neighborhood and the inclination to litter without care. Individual character-building should be encouraged within children to become moral members of society, ultimately leading to producing a distinguished nation.

(C) The Author(s). 2021

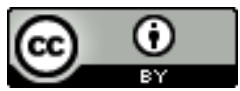

This work is licensed under a Creative Commons Attribution 4.0 International License 
As the nation's next generation, students are directed through individual characterbuilding to have good morals and values to result in a nation that lives fairly, safely, and prosperously (Putri, 2018). In 2013, the Indonesian government, mainly through the acts of the Ministry of Education and Culture (Kementrian Pendidikan dan Kebudayaan, Kemendikbud), started to push forward the planting of these values through schools. The ministry chose to do this by changing to a new curriculum, known as the 2013 Curriculum, from the existing Kurikulum Tingkat Satuan Pendidik (KTSP). There are 18 values stated for the purpose of character building (Hasan, 2009), including: 1. Religiousness; 2. Honesty; 3. Tolerance; 4. Discipline; 5. Hard work; 6. Creativity; 7. Independence; 8. Democracy; 9. Curiosity; 10. Spirit of Nationality; 11. Love for the Nation; 12. Appreciation for Achievements; 13. Friendly/Social; 14. Love for Peace; 15. Fondness for Reading; 16. Environmental Awareness; 17. Social Awareness; 18. Responsibility. In 2016, the Kemendikbud conducted a revolution of the nation's values. They implemented Penguatan Pendidikan Karakter (PPK) to support character building. The five main values listed as prioritized values in the PPK include: 1. Religiousness; 2. Nationalism; 3. Gotong royong (Communal work or working together); 4. Integrity; 5 . Independence.

Based on the 18 character values and the five main prioritized values, the value of environmental awareness seems interesting to analyze. Integrity is the practice of constantly being honest in word, action and having the commitment and loyalty to stay within humanity's values and morals (Kemendikbud, 2017). Environmental awareness is the attitude and act of constantly preventing the destruction of the environment in addition to developing methods of mending damage that has already been done to the environment (Hasan, 2009).

\section{Problem of Study}

As Indonesia enters the millennial era, environmental awareness has started to decline within the nation. Many citizens litter, illegally cut down trees, do not care for animals and plants around them accordingly, and so on. Humans do not realize that it is their doings that lead to natural disasters. Due to this, environmental awareness must be planted in children from when they are young. In Al-Quran Q.S 31:17, Allah SWT said O my dear son, establish prayer, encourage what is good and forbid what is evil, and endure patiently whatever befalls you (Fu'adah \& Nugraheni, 2020). Indeed these are the things that Allah requires.

Implementation of the environmental awareness character in the 2013 curriculum can be done maximally by education providers, mainly teachers. Teachers can maximize implementation when supported by appropriate tools. The teacher and student books developed by the Kemendikbud can be used as one of these supportive tools. In theme three of the fourth-grade book, they discuss caring for all living creatures, which is of interest to this study. An analysis was done to observe whether the value of environmental awareness, such as caring for plants, animals, and helping one another, has been implemented in theme 3 of the fourth-grade student book.

\section{State of the Art}

Similar studies regarding the analysis of books for character-building values have previously been done. Rahma (2018) analyzed character-building values in theme 4 of the 2013 curriculum year three student book that discussed social awareness. Adi (2018) examined the contents of primary textbooks for character-building purposes. Sayekti (2019) analyzed the core principles of natural science education in theme three, subtheme one of the 2013 curriculum year four student book. Danawati et al. (2020) investigated the characteristic values in thematic student books that discussed character building. Permatasari \& Anwas (2019) analyzed character-building in year seven natural sciences textbooks. Mardikarini \& Suwarjo (2016) studied the values contained in the 2013 curriculum teacher and student textbooks. Hutama et al. (2019) analyzed the character- 
building contents in the reading portions of the year four student book with the theme of the beauty of togetherness. Rahayuningtyas (2013) examined contents of character values in the 2013 curriculum primary teacher and student handbooks. Lastly, Kusmilawati et al. (2019) analyzed the character values of year four students during the Indonesian language subject while they were learning to read.

\section{Gap Study \& Objective}

This study hoped to improve teachers' understanding of the character-building values of environmental awareness stated in theme 3 of the year four student book. With this improved understanding, teachers will innovate their education delivery methods and provide students with the best education. Ultimately, this will supply students with values regarding environmental awareness that are targeted and maximized. It would produce a future generation that is noble, as well as socially and environmentally aware.

\section{METHOD}

\section{Type and Design}

This study is descriptive qualitative research facilitating a document study design. The document source is the 2017-revised version of theme three of the year four student book published by the Ministry of Education and Culture, as well as journals and literature related to our discussion.

\section{Data and Data Sources}

Data from this study are sentences from theme three of the year four student book that contains character-building values of environmental awareness. This study facilitated both primary and secondary data. Primary data were collected directly from the primary data source, namely theme three of the year four student book. On the other hand, secondary data were collected from book identification, relevant past studies, and other data or references that may be correlated to our interests.

\section{Data collection technique}

\section{Documents}

The documents technique is used to collect data sourced from writing such as books and journal articles.

\section{Data analysis}

Data validity was tested using semantic validity and reliability stability. Semantic validity was used to judge the appropriateness of the researched meaning, which is the value of environmental awareness in theme three of the year four student book. Reliability stability was done by repeated reading of the obtained data to ensure the same understanding of the studied document each time.

\section{RESULT}

\section{Social Awareness}

1. On page four, "Let's Observe," there is a picture of a group of people pulling a fishing net out from the sea. This activity was done by helping one another (gotong royong) and reflects the value of social awareness. 

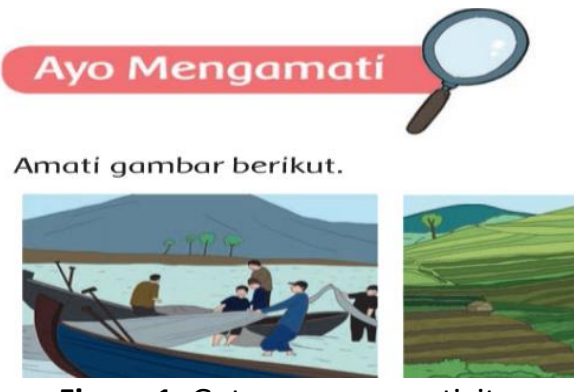

Figure 1: Gotong royong activity

2. On page 98, in the third question under "Let's Try", the sentence "inviting friends and family to do the same thing". The word inviting depicts the value of social awareness.

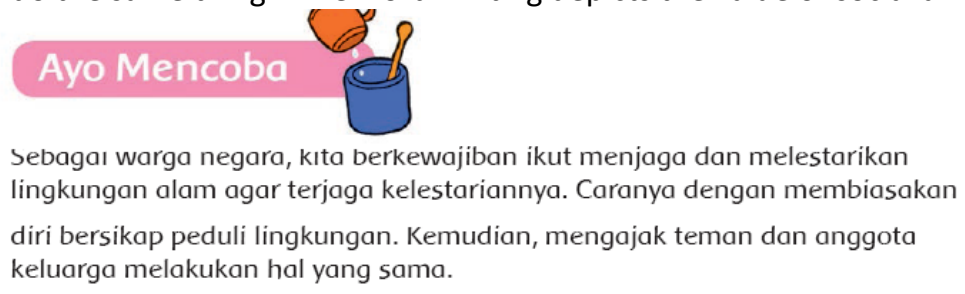

Figure 2: The word "inviting"

3. On page 114, the sentence "discuss other examples of caring for the environment with your friend!". This discussion activity will train students to voice their opinions as well as improve their listening skills. Students were asked to pick out solutions that they will do themselves. The word discussion depicts values of caring for the environment, an indicator of social awareness.

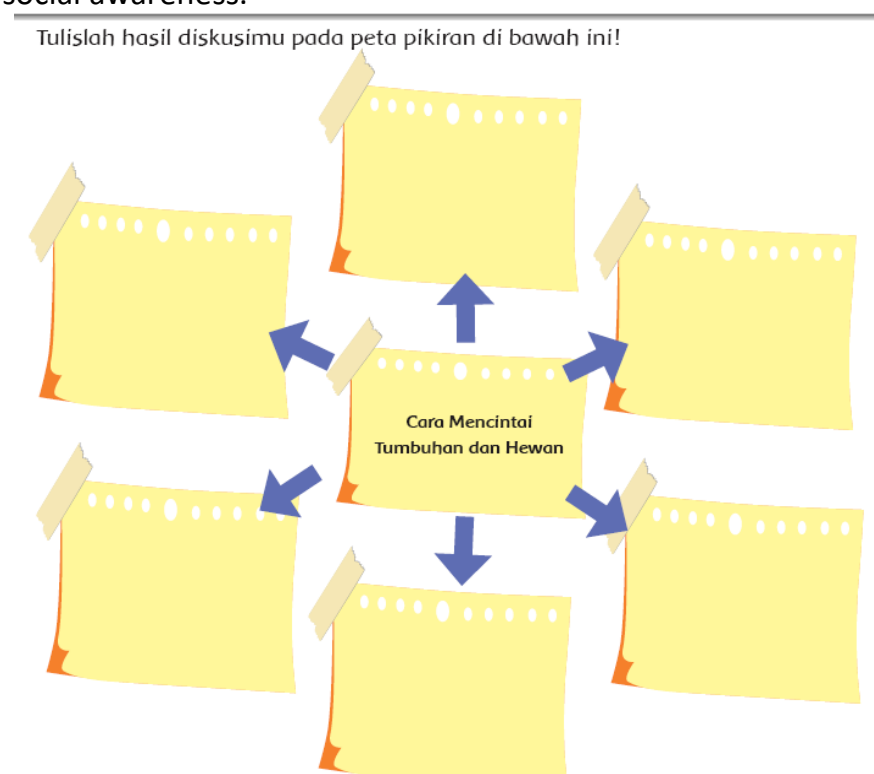

Figure 3: The word "discussion"

4. On page 140, there is a story entitled "Community service in the school garden". This story depicts that working together will make the task complete earlier and the environment cleaner in a shorter amount of time. This activity contains values of social awareness as well as care for plants. 


\section{Kerja Bakti di Kebun Kelas}

Di sekolah Dira, tiap kelas memiliki sepetak kebun kelas. Jenis tanaman
yang dipelihara di kebun kelas disepakati bersama oleh semua siswa
di kelas. Dira dan teman-temannya sepakat untuk memiliki sepetak
kebun sayur. Mereka berdiskusi dengan Pak Wira, guru kelas mereka
untuk menentukan jenis sayur yang dapat mereka pelihara bersama.
Mereka pun memutuskan untuk memelihara tanaman sayur bayam dan
kangkung. Selain cukup mudah dalam pemeliharannna, masa tanam
hingga panen untuk kedua jenis sayur ini cukup singkat. Kurang lebilh 3-4
minggu mereka sudah dapat menikmati hasil panennya.
Semua siswa di kelas membawa satu buah pot untuk diletakkan di kebun
kelas. Bibit kangkung dan bayam dicarikan oleh Pak Wira. Semua siswa
melakukan penanaman mandiri, yang didampingi oleh Pak Dudi, tukang
kebun sekolah. Cukup mudah cara menanamnya. Setelah itu, Dira dan
teman-teman membuat jadwal piket pemeliharaan. Mereka mengatur
sendiri agar semua siswa memperoleh jadwal penyiraman. Pagi dan sore,
setiap hari! Ya, setiap sore pun ada siswa yang harus datang kembali ke
sekolah untuk menjalankan tugas menyiram tanaman. Di hari sabtu dan
Minggu pun ada siswa yang bergiliran datang untuk menyiram. Begitu
pun jadwal pemberian pupuk. Mereka mengatumya sendiri. Semua siswa
harus terlibat dalam mengelala kebun kelas.
seminggu setelah ditanam, ternyata tanaman bayam dan kangkung
yang mulai meninggi kering kerantang terkena panas matahari yang
menyengat. Dira dan teman-teman sempat sedih. Namun, Pak Dudi dan
Pak Wira mengingatkan mereka untuk tetap bersemangat. Memelihara
tanaman memang sesekali akan menemui masalah, namun mereka
harus belajar dari masalah yang ditemui, jangan mudah menyerah. Dira
dan teman-teman kembali membangun semangat. Mereka melakukan
penanaman ulang, memelihara lagi dari awal.
Sebulan kemudian mereka memetik hasilnya. Kangkung dan bayam di
kebun kelas tumbuh subur, hijau segar. Panen sayur dilakukan bersama-
sama oleh Dira dan teman-temannya. bbu Dira dan ibu-ibu yang lain
datang di hari panen. Mereka membantu Dira dan teman-teman
memasak sayur bayam dan tumis kangkung untuk dimakan bersama.
Berbeda rasanya, makan sayur hasil panen dari kebun sendirl. Berbeda
msanya makan sayur hasil kerja bakti di kebun kelas.

Figure 4: The sentence "Community service in the school garden"

\section{Care for Plants}

1. On page 40 , the sentence "the following are some ways to the sustainable growth of rice so that it can continue to be enjoyed by the Indonesian community." The word "sustainable" means to protect or preserve to maintain. The phrase "sustainable growth of rice" depicts care for plants.

Berikut adalah beberapa cara untuk mempertahankan padi tetap dapat dinikmati masyarakat Indonesia.

1. Menjaga bibit agar dapat ditanam kembali.

2. Menjaga lahan pertanian. Jangan sampai lahan digunakan untuk kebutuhan lainnya, misalnya dijadikan untuk mendirikan bangunan.

3. Menjaga kebersihan lingkungan sekitar. Sampah akan menyebabkan banjir. Apabila terjadi banjir, maka tanaman padi tidak akan tumbuh.

4. Saluran air dijaga agar tetap mengalir.

5. Penggunaan beras yang tidak berlebihan. Jumlah penduduk yang meningkat akan meningkatkan kebutuhan yang besar terhadap padi. Penggunaan beras sesuai kebutuhan akan sangat membantu.

Figure 5: The sentence "How to sustain rice"

2. On page 10, there is a table that contains the question, "Have you taken advantage of plants wisely?" The word "taken advantage of plants" depicts care for plants. 
Sekarang, lihatlah dirimu. Apakah kamu sudah memanfaatkan tumbuhan dengan bijak.

\begin{tabular}{|l|l|}
\hline Pernyataan & Uraian \\
\hline $\begin{array}{l}\text { Contoh sikapmu yang sudah bijak } \\
\text { terhadap tumbuhan }\end{array}$ & \\
\hline $\begin{array}{l}\text { Dampak dari sikapmu tersebut bagi } \\
\text { lingkungan }\end{array}$ & \\
\hline $\begin{array}{l}\text { Contoh sikapmu yang belum bijak } \\
\text { terhadap tumbuhan }\end{array}$ & \\
\hline $\begin{array}{l}\text { Dampak dari sikapmu yang belum } \\
\text { bijak tersebut bagi lingkungan }\end{array}$ & \\
\hline $\begin{array}{l}\text { Apa rencanamu untuk } \\
\text { memperbaikinya }\end{array}$ & \\
\hline
\end{tabular}

Figure 6: The word "taken advantage of plants"

3. On page 24, "Let's read", there is a text entitled "Lani and her Younger Sibling". It tells the story of Lani who constantly maintains the plants in their home and her younger sibling who often forgets to take care of the plants. Lani's actions reflect the value of care for plants.

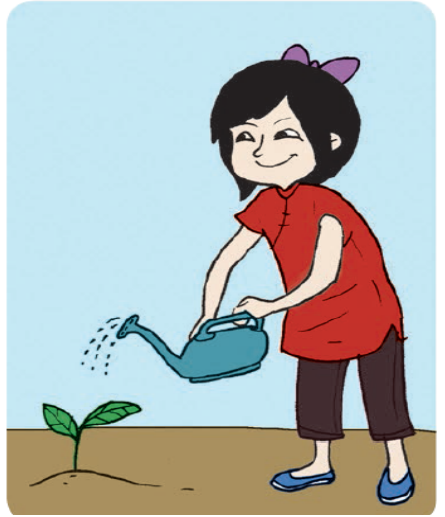

\section{Lani dan Adiknya}

Lani mempunyai tanaman yan

ditanamnya di rumah. Setiap pagi

dan sore hari, Lani selalu menyiram

tanamannya. Selain menyiram Lani juga

memberikan pupuk seminggu sekali. Tanaman Lani tumbuh dengan subur.

Adik Lani juga mempunyai tanaman yang ditanam di rumah. Sering kali, ía lupa untuk menyiram tanamannya. la juga jarang memberikan pupuk. Lani sudah sering mengingatkan adiknya. Namun, adik Lani selalu lupa. la lebih senang menonton TV dan bermain. Tanaman miliknya layu dan hampir mati.

Figure 7: The text "Lani and her younger sibling"

4. On page 26 , there is an activity section that contains the activity "Create a schedule to take care of a plant that you have planted. Be disciplined in following the schedule!". This activity teaches students to care for plants and to be disciplined in maintaining plants that they have planted.

Buatlah jadval merawat tanaman yang sudah kamu tanam. Disiplinlah dalam melakukannya.

\begin{tabular}{|l|l|l|}
\hline Hari & Kegiatan di pagi hari & Kegiatan di sore hari \\
\hline Senin & & \\
\hline Selasa & & \\
\hline Kabu & & \\
\hline Jum'at & & \\
\hline Sabtu & & \\
\hline Minggu & & \\
\hline
\end{tabular}

Figure 8: Schedule for Maintaining your Plant 
5. On page 45, there is the question "What have you done well while caring for that plant? Explain!". This question will teach students to recall past activities that they have done to care for the plants they planted. This question contains the value of care for plants.

Apa yang sudah kamu lakukan dengan baik selama merawat tanaman tersebut? Jelaskan.

Figure 9: The question regarding caring for plants

6. On page 97, there are pictures of animals and plants that are cared for and not cared for. Students were asked to observe these pictures and to give a tick on which animals and plants were maintained well. This activity will directly stimulate the students' brains in differentiating which plants and animals were taken care of and which of them were not. This activity reflects environmental awareness, care for animals and plants indicator.

Ayo, amati gambar berikut. Berilah tanda centang $(\checkmark)$ pada gambar yang menunjukkan tanaman dan hewan yang terawat.
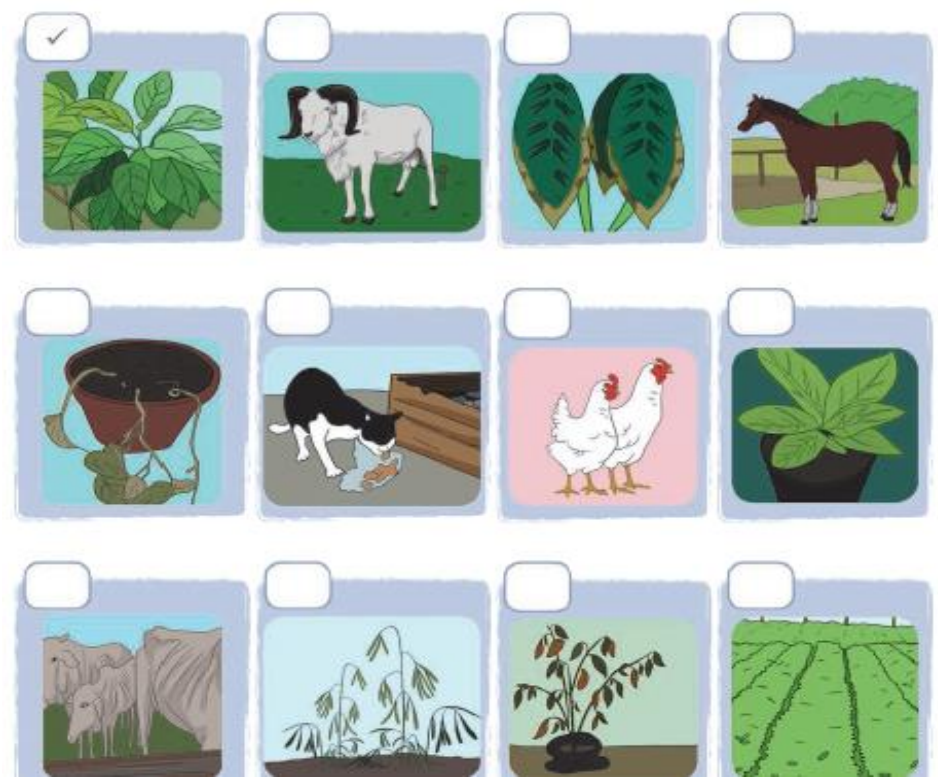

Figure 10: Choosing plants and animals that were taken care of

7. On page 136, there is a story entitled "Beautiful flower in the town garden". The story depicts that we must take care of all plants in that garden and it contains the value of care for plants. 

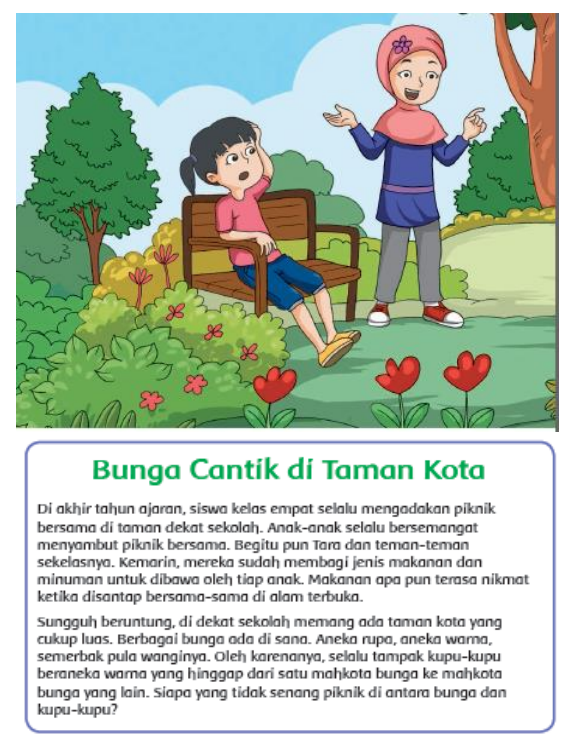

Figure 11: The story "Beautiful flower in the town garden"

8. On page 141 , there is a story entitled "To-be fruits must be cared for". The story explains that before picking fruits from the trees, we must first ensure that it is ripe and ready. This story depicts the value of care for plants.
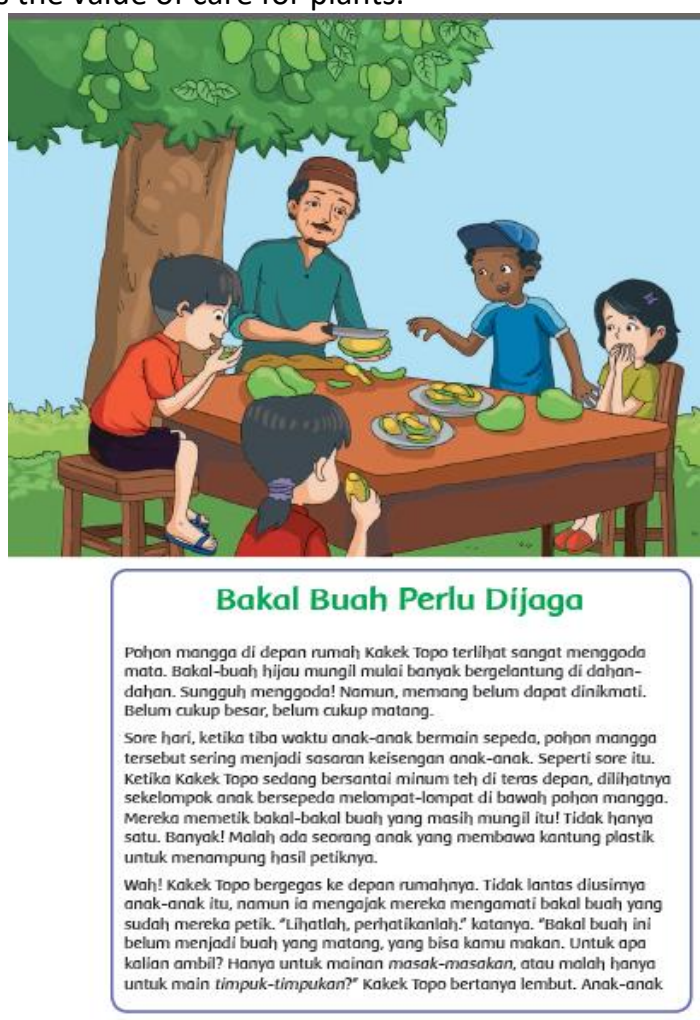

Figure 12: The story "To-be fruits must be cared for"

Care for Animals 
1. On page 49 , there is the question "What can be done to preserve the sustainability of the bird of paradise?". This question is one where the answer will reflect the value of care for animals.

Apa yang bisa dilakukan untuk menjaga kelestarian burung cenderawasih?

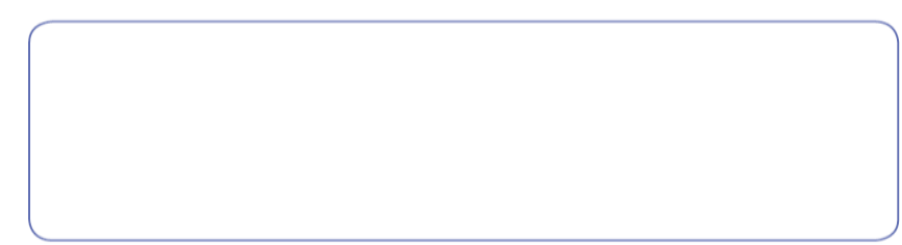

Figure 13: The question about preserving the sustainability of the bird of paradise

2. On page 52 , there is the question "What can you do to protect butterflies?". This question reflects the value of care for animals.

2. Apa yang bisa kamu lakukan untuk melindungi kupu-kupu?

Figure 14: The question about protecting butterflies

3. On page 52 "Let's create", students are directed to make posters about preserving the sustainability of animals. This activity depicts the value of care for animals.

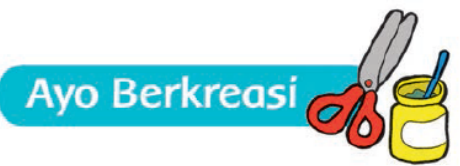

Kamu telah mengetahui tentang manfaat penting hewan bagi keseimbangan lingkungan.

Nah, sekarang kamu bisa ikut berperan serta untuk menjaga kelestarian hewan dengan membuat poster.

Buatlah sebuah poster yang berisi ajakan untuk menyayangi dan merawat hewan.

Figure 15: Making a poster activity

4. On page 54, there is a story entitled "Dayu and Si Mungil". The story depicts the value of care for animals. 
Dayu mempunyai hewan peliharaan. Ayo kita baca cerita Dayu.

Dayu dan Si Mungil

Sudah sejak lama Dayu ingin
punya hewan peliharaan. Dayu
ingin memelihara kucing. Dulu, ibu
berjanji Dayu boleh memelihara
kucing ketika Dayu sudah cukup
besar. Kata ibu, Dayu bisa
mempunyai hewan peliharaan
jika sudah mandiri dan bisa
bertanggung jawab.
Sekarang Dayu sudah kelas 4 SD.
Senang sekali hatinya ketika suatu
hari ibu memberinya izin untuk
memelihara seekor kucing. Setiap
sore, kucing belang berwarna
hitam-cokelat itu berkeliaran
di halaman rumah Dayu. Dayu
memberinya nama Si Mungil,
sesuai dengan tubuh mungilnya.

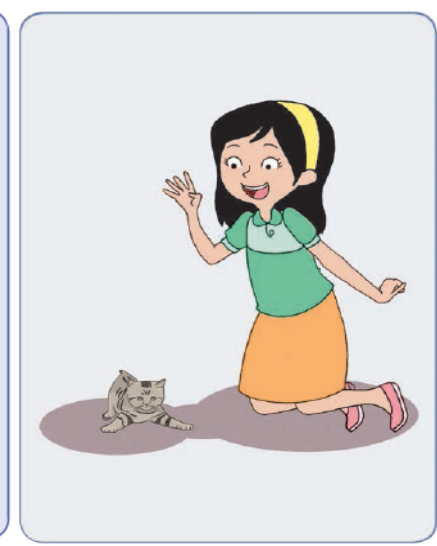

Figure 16: The story Dayu and Si Mungil

5. On page 57 "let's write", students were tasked to write about their experiences in caring for their pets. This activity reflects the value of care for animals.

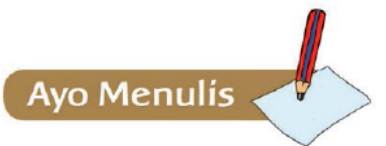

Bagaimana dengan kamu, apakah kamu mempunyai hewan peliharaan Apakah kamu sudah merawatnya. Tulislah ceritamu.

Hal-hal yang kamu tulis:

1. Hewan peliharaanmu.

2. Kenapa kamu merawatnya.

3. Bagaimana kamu merawatnya.

4. Apakah kamu sudah melaksanakan kewajibanmu.

5. Dampak bagi hewan peliharaan dan lingkunganmu.

6. Apakah kamu sudah mendapatkan hak.

7. Apakah kamu sudah melaksanakan hak dan kewajiban secara seimbang.

8. Rencanamu untuk memperbaiki jika hak dan kewajiban belum seimbang.

Figure 17: Writing a story about taking care of pets

6. On page 92 , there is a story entitled "Maintain the sustainability of rare animals". This story is about efforts that can be done to protect and sustain animals that are near extinction. It depicts the value of care for animals. 
Baca teks berikut.

\section{Lestarikan Hewan Langka.}

Pelestarian hewan langka bertujuan agar hewan tersebut tidak mengalami kepunahan. Kelestarian hewan sangat bermanfaat untuk kelangsungan hidup manusia.

Sebagai warga negara kita mempunyai kewajiban dan tanggung jawab untuk melindungi dan melestarikan hewan-hewan langka tersebut.

Beberapa upaya yang bisa dilakukan untuk menjaga hewan langka, antara lain:

1. melakukan penangkaran hewan langka.

2. mendirikan tempat-tempat perlindungan hewan langka, misal: suaka margasatwa, cagar alam, kebun binatang, dan taman nasional.

Dengan melindungi hewan langka kita dapat:

1. menjaga keseimbangan ekosistem agar kehidupan di muka bumi tetap berjalan dengan baik;

2. melestarikan keanekaragaman hayati yang bermanfaat bagi ilmu pengetahuan dan masyarakat;

3. memenuhi kebutuhan masyarakat, misalnya untuk bahan pangan dan obat-obatan.

Figure 18: The story maintains the sustainability of rare animals

7. On page 134, the story is entitled "Let si Cuwit fly freely!". The story explains that we have to let birds fly free and that reflects the value of care for animals.

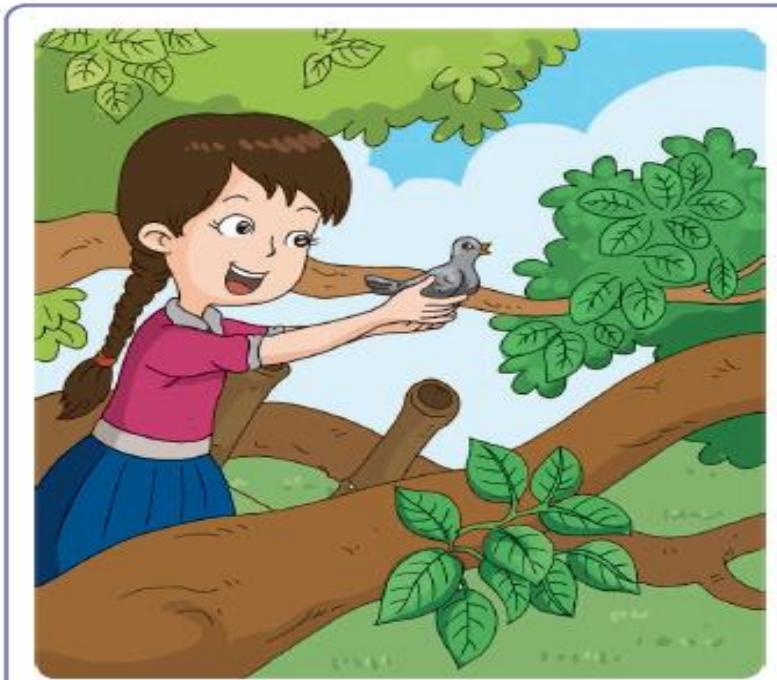

Biarkan Si Cuwit Terbang Bebas!

Ketika liburan di rumah nenek, Cica selalu menyempatkan berjalan pagi di sekitar rumah. Udara pagi yang sejuk di kaki gunung tidak dirasakannya ketika ada di numahnya, di Jakarta. Oleh karenanya, Cica tidak mau melewatkan kesempatan berharga tersebut. la selalu bangun sebelum matahari terbit. Kadang-kadang, kakek menemani Cica berjalan pagi. Tetapi hari ini kakek harus mengantar telur ayam ke pasar sehingga tíl.

Cica berjalan di antara rimbun pohon dan wangi bunga di pagi hari. Semalam hujan cukup deras, sehingga wangi daun dan tanah basah

Figure 19: The story let si Cuwit fly freely! 
8. On page 138, the story is entitled "Kiki and Lala, beloved rabbits". The story teaches students to care for their pets. It contains the value of care for animals.

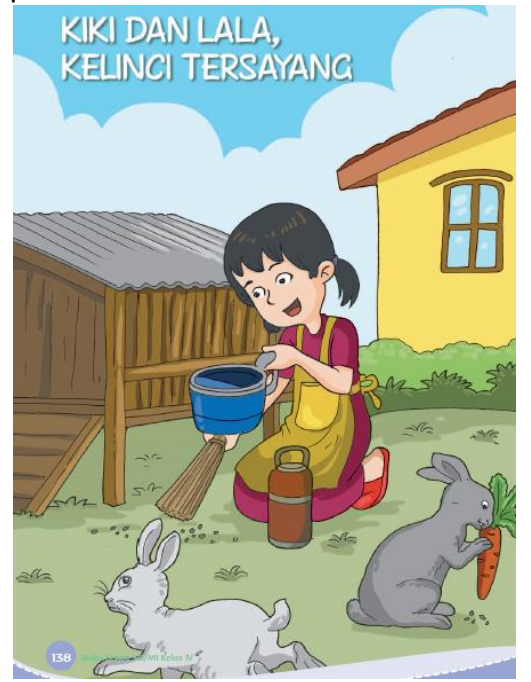

Figure 20: The story Kiki and Lala, beloved rabbits

\section{DISCUSSION}

Character building during primary school is one of the main beginning of planting morals in a child. In this primary school age, children are still in the concrete operational stage of their development. During this stage, children require real things and examples when learning components regarding character building. Character building during primary school is not the task and responsibility of the teachers alone, but also all members of the society, which are responsible for building the characters of our future generation. However, parents and family share the main responsibility in building a child's personality, as they spend most of their time with family compared to at school.

With the constantly developing times, Indonesia has now moved into the disruption era. This era is marked by how society's activities are shifted from the originally face-to-face to a virtual manner. The disruptive age demands humanity to understand and facilitate their knowledge and information and communication technology. This era has also involved many fields, including education. Many parents experience difficulties when their children need to study using today's technologies, one of which is advanced gadgets. The difficulties experienced by parents range from them being unable to provide these gadgets as it is not cheap, being unable to operate the gadget, and being unable to supervise their children's use of the devices because of a packed routine. As a result, character-building should also be done at school. The school environment and teachers are now considered an essential key to a student's successful character building. This is in line with what Milson and Mehling in Rusminiati (2016) mentioned that teachers are an important factor in the development of an individual's character at a young age. As such, teachers must be able to provide an excellent example of behavior in schools as well as in the surrounding environment.

Only providing an excellent example of behavior is not sufficient. Teachers must also voice these out to children through subjects devised to build character. This is supported by Judiani (2010), saying the Indonesian education system is too focused on developing cognition and academics but lacks soft skills or nonacademic development. This leads to the need for a curriculum that considers values that build character during the education process. The Indonesian government, specifically the Ministry of Education and Culture, decided to change the previously used KTSP to the 2013 curriculum in response to this. 
In theme three, "Care toward living things" of the year four student book, environmental awareness was discussed in all sub-themes but not in every Learning Sections. In the first sub-theme, "Animals and plants around my house", there was an emphasis on the environmental awareness character-building indicator care toward plants. Care for plants were also existent in Learning Section 1, Learning Section 2, Learning Section 3, Learning Section 4, and Learning Section 6. Sub-theme one also contains components of environmental awareness character building, emphasizing the indicator of care toward other people. This was found in Learning Section 1. Care toward plants, which is one indicator of environmental awareness character building, must be taught to students from a young age. This is done so that students have an awareness and the sense of owning over the plants around them from an early stage. A sense of ownership is necessary as students will then be disciplined in maintaining and caring for it. As a result, there will be no more destruction of nature in the future, such as mass deforestation, littering, and so on. This will lead to the sustainability of the natural resources found in Indonesia. Habituation of values in environmental awareness character building can be seen through several activities, including reading texts, pictures as well as discussions with other students to share in between each other and protect the environment well (Judiani, 2010). In sub-theme one, "Animals and Plants around my neighborhood" of theme three, "Care toward living things" of the year four student book, the subject matter of caring for plants was presented well. However, no subject matter correlates to caring for animals.

In sub-theme two, "The variety of living things around me" of theme three, "Care toward living things" of the year four student book, the indicator care for animals of environmental awareness character building is existent. This can be found in Learning Section 1, Learning Section 2, and Learning Section 6. In theme three, "Care toward living things" of the year four student book, caring for animals was emphasized by protecting rare animals such as the bird of paradise and caring for pets such as cats. In sub-theme two, only the indicator care for animals was existent. The indicators caring for plants and caring for other human beings were not present.

In the year four student book, all three indicators were present in sub-theme three of theme three, "Care toward living things," in the year four student book. Sub-theme three is complimentary for the previous sub-themes. In addition, it also contains literacy-building aspects based on caring for plants, caring for animals, and caring for other human beings. Reading texts in theme 3, "Care toward living things", of the year four student book further supports the use of this book as teaching material. The building of literacy is aimed at improving students' understanding of the importance of environmental awareness. (Meilani, 2013) mentions that the integration of character building in school teachings can be done by adding character-building values into all school subjects and teaching activities. Theme three, "Care toward living things," of the year four student book contains values of environmental awareness character building and is suitable to be used as teaching material.

Theme three, "Care toward living things," of the year four student book can be used as teaching material. Teachers are required to be innovative in their education delivery methods. This is so that the students can absorb environmental awareness values found in the student book in a targeted and maximized manner. If this is done well, then the goal of character building has been achieved, leading to a future generation with distinguished personalities.

\section{CONCLUSION}

Novelty and Contribution

Divided dimensions hindered previous studies on environmental awareness. A comprehensive environmental awareness character building would produce a future 
generation that is pious, noble, virtuous, and distinguished. This study discussed the implementation of environmental awareness character-building comprehensively. The results of this study are important for all primary school educators to produce a creative learning environment in building students' environmental awareness.

\section{Limitation and Future Study}

This study has several limitations. Firstly, the characteristic value of caring for other human beings that were found was minimal. This limitation in teaching resources resulted in the lack of its delivery to students. Secondly, the author has chosen to only discuss one theme among the eight existing themes studied by the students, which may lead to an incomprehensiveness of data. It will be great if future studies on environmental awareness focus on adding care for other human beings into the next version of theme three of the year four student book.

\section{Implication / suggestions}

This study would like to provide three recommendations. Firstly, the Ministry of Education and Culture (Kemendikbud) is suggested to equalize subject matters in theme three of the year four student book. This includes an even discussion of the topics of care for other humans, animals, and plants. Secondly, teachers must be innovative and creative in their education delivery methods. Finally, parents must be supportive and work in cooperation with teachers in producing distinguished characters in students.

\section{REFERENCES}

Adi, Y. K. (2018). ANALISIS MUATAN PENDIDIKAN KARAKTER DALAM BUKU TEKS KURIKULUM 2013 KELAS III SD SEMESTER 1. Profesi Pendidikan Dasar, 1(1), 23. https://doi.org/10.23917/ppd.v1i1.3754

Danawati, M. G., Regina, B. D., \& Mukhlishina, I. (2020). Analisis Nilai Karakter pada Buku Siswa Tematik Sekolah Dasar Berorientasi Pendidikan Karakter. Jurnal Pemikiran dan

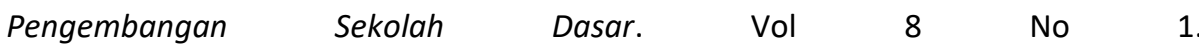
https://doi.org/10.22219/jp2sd.v8i1.12369.

Fu'adah, E. N., \& Nugraheni, Y. T. (2020). Perintah Shalat pada Anak Perspektif Surat Luqman Ayat 17 (Telaah Pendekatan Normatif dan Filologi). 8(1), 9.

Hasan, S. H. (2009). Pengembangan Pendidikan Budaya dan Karakter Bangsa. Badan Penelitian dan Pengembangan Pusat Kurikulum.

Hutama, F. S., Anhar, H. A., \& Haidar, D. A. (2019). Muatan Nilai-Nilai Pendidikan Karakter dalam Teks Bacaan Pada Buku Siswa Kelas IV Tema Indahnya Kebersamaan. 1, 16.

Judiani, S. (2010). Implementasi Pendidikan Karakter di Sekolah Dasar Melalui Penguatan Pelaksanaan Kurikulum. Jurnal Pendidikan dan Kebudayaan, 16(9), 280. https://doi.org/10.24832/jpnk.v16i9.519

Kusmilawati, F. E., Hadi, H., \& Agustini, F. (2019). Analisis Nilai Karakter Siswa Kelas IV pada Prose Pembelajaran Bahasa Indonesia Materi Membaca. Indonesian Values and Character Education Journal, 2(1), 1. https://doi.org/10.23887/ivcej.v2i1.17923

Mardikarini, S., \& Suwarjo, S. (2016). ANALISIS MUATAN NILAI-NILAI KARAKTER PADA BUKU TEKS KURIKULUM 2013 PEGANGAN GURU DAN PEGANGAN SISWA. Jurnal Pendidikan Karakter, 6(2). https://doi.org/10.21831/jpk.v6i2.12057

Meilani, E. (2013). ANALISIS MUATAN NILAI KARAKTER DALAM BUKU TEKS BAHASA INDONESIA KELAS XI KURIKULUM 2013 REVISI 2017. 16.

Kemdikbud. (2017). Penguatan Pendidikan Karakter Jadi Pintu Masuk Pembenahan Pendidikan Nasional. Kementerian Pendidikan Dan Kebudayaan. https://www.kemdikbud.go.id/main/blog/2017/07/penguatan-pendidikan-karakter- 
jadi-pintu-masuk-pembenahan-pendidikan-nasional

Permatasari, A. D., \& Anwas, E. O. M. (2019). ANALISIS PENDIDIKAN KARAKTER DALAM BUKU TEKS PELAJARAN ILMU PENGETAHUAN ALAM KELAS VII. Kwangsan: Jurnal Teknologi Pendidikan, 7(2), 156. https://doi.org/10.31800/jtp.kw.v7n2.p156--169

Putri, D. P. (2018). Pendidikan Karakter Pada Anak Sekolah Dasar Di Era Digital. AR-RIAYAH : Jurnal Pendidikan Dasar, 2(1), 37. https://doi.org/10.29240/jpd.v2i1.439

Rahayuningtyas, D. I. (2013). AN ANALYSIS OF CONTENT OF CHARACTER VALUES IN THE TEXTBOOK OF 2013 CURRICULUM FOR HANDBOOKS OF TEACHER AND STUDENT IN PRIMARY SCHOOL. Jurnal Pendidikan Karakter, 17.

Rahma, D. P. K. (2018). ANALISIS NILAI-NILAI PENDIDIKAN KARAKTER PADA BUKU SISWA KELAS III TEMA 4 "PEDULI LINGKUNGAN SOSIAL" KURIKULUM 2013.

Rahmalah, P. Z., Astuti, P., \& Pramessetyaningrum, L. (2019). PENGARUH PENGGUNAAN GADGET TERHADAP PEMBENTUKAN KARAKTER ANAK USIA DINI. 9.

Sayekti, I. C. (2019). ANALISIS HAKIKAT IPA PADA BUKU SISWA KELAS IV SUB TEMA I TEMA 3 KURIKULUM 2013. Profesi Pendidikan Dasar, 1(2). https://doi.org/10.23917/ppd.v1i2.9256

Siahaan, I., \& Fransyaigu, R. (2020). Analisis Nilai Karakter Yang Terkandung Pada Buku Teks Siswa Sekolah Dasar. 3(1), 15. 